\title{
ENVIGPGIKA
}

Envigogika: Charles University E-journal for Environmental Education ISSN 1802-3061

\section{Životní prostředí pohledem Bible}

\section{Jiří Nečas}

Envigogika 13 (1) - Recenzované články/ Reviewed articles

Publikováno / Published 15. 6. 2018

DOI: $10.14712 / 18023061.567$

\section{Abstrakt}

Zájem o životní prostředí ve většině křestanských církví se vyvíjel zpočátku poněkud rozpačitě. Článek ukazuje, že Bible vede k environmentální odpovědnosti. Odvolává se při tom na různá místa z Bible. Zdůrazňuje, že křestán se musí angažovat pro dobro, přičemž životní prostředí je pro křestana součástí dobrého božího stvořitelského díla.

\section{Klíčová slova}

Bible; životní prostředí; angažované křestáanství

\section{Abstract}

An interest in the environment in most Christian religions developed in a somewhat confused way at first. Referring to various passages in the Bible the article shows that the Bible takes a lead on environmental responsibility. It emphasizes that Christians must engage to work towards good, while the environment is - in a Christian understanding - already a part of God's good work of creation.

\section{Key words}

Bible; environment; committed Christianity 


\section{1. Úvod}

\section{1. Člověk a životní prostředí}

Vzájemná závislost mezi člověkem a životním prostředím je velice silná. O závislosti člověka na jeho okolí asi nikdy nebylo pochyb, avšak v obráceném smyslu, o závislosti lidského okolí, tedy prírody, životního prostředí na člověku se v minulosti neuvažovalo. Mnozí máme v paměti velikášská komunistická hesla typu „Poručíme větru dešti”. O jejich nesmyslnosti dnes není pochyb; ta však spočívá především jinde než v jejich technické neuskutečnitelnosti. Odpověd', proč obsah oněch hesel z dob, kdy ještě komunismus obsahoval či aspoň předstíral určité nadšení, je nesmysıný, nacházíme v Písmu. První kapitola Bible opakovaně svědči o tom, že co Bưh stvořil, bylo dobré, resp. nakonec velmi dobré. Svými bezohlednými zásahy, vymykajícími se poslání pečovat o stvoření $(G n 2,15)$, člověk mưže Boží dílo jedině pokazit. A tím, že o takovýchto zásazích vůbec uvažuje, podobá se lidem zahajujícím stavbu věže $v$ Bábel. Ta skončila tím, že se lidé nebyli schopni domluvit. Pýcha a velikášství k ničemu dobrému nemohou vést a neschopnost domluvy je jejich důsledkem. Složitost a provázanost současného světa znamenají, že řešení velkých problémů dneška je společným úkolem pro celé lidstvo. Tato nutná společná akce však nesmí probíhat ve znamení pýchy, nýbrž naopak, musí být provázena hlubokou pokorou. Je třeba spojit své síly a společně hledat cestu k nápravě toho, co jsme my lidé pokazili.

\subsection{Krize životního prostředí}

Během posledních cca 150 let, a zvláště pak v druhé polovině dvacátého století došlo a stále dochází k závažnému poškození životního prostředí, přičemž významným zdrojem těchto životu nepřiznivých změn je lidská činnost. Člověk mění složení atmosféry, což přispívá ke změně klimatu (globální oteplování). Antropogenní růst podílu $\mathrm{CO}_{2}$ atmosféře je alarmující také proto, že jeho malý podíl souvisí s existencí života na Zemi (srov. Lovelock 1993, Lovelock 2008).

O narušení hydrosféry (zemského vodstva) se mluvívá méně než o jiných negativních důsledcích lidské činnosti. Nicméně lidská činnost přispívá k tomu, že pitná voda je stále vzácnější. Ubývá sladkovodních i mořských ryb a dalších vodních živočichů, ohroženy jsou mořské řasy, což vzhledem k jejich možné významné roli při absorbování oxidu uhličitého a produkci kyslíku může mít pro život na Zemi doslova fatální důsledky. Svědectvím o prakticky neomezených lidských destrukčních možnostech vzhledem k hydrosféře je rychlé vysychání Aralského jezera, které začalo za sovětské vlády (Feshbach 1992).

I stav pevného zemského povrchu včetně flory a fauny je narušován nejrozmanitějšími lidskými činnostmi (např. ubývání tropických pralesů a s ním spojené zanikání živočišných a rostlinných druhů, snižování retenčních schopností zemského povrchu). Fyzické životní prostředí je narušováno i dalšími faktory, jako např. hlukem či světelným smogem.

Změny životního prostředí se promítají zpravidla neblaze do zpưsobu života. Například ve své podstatě dobrá a zdravá pěší chůze ve znečištěných, auty a exhaláty zamořených a hlučných městských ulicích ztrácí své pozitivní účinky na zdraví a použití dopravního prostředku se stává téměř nutným, čímž se však situace ještě zhoršuje. $V$ důsledku narušování životního prostředí dochází k nedobrým změnám v sociálním klimatu.

Různé analýzy stavu životního prostředí ukazují, že situace je daleko vážnější, než si my lidé připouštíme a do svého počínání promítáme. Zvlášt́ nezodpovědné je počínání vlád, které ji do legislativy (včetně daňových systémů) bud' nepromítají vůbec, nebo jen velmi pomalu. Ekonomický systém charakteristický pro dnešní Evropu, Severní Ameriku (a prakticky pro celý globalizující se svět) se opírá o představu stálého materiálního růstu, která je 
z hlediska životního prostředí zcela neoprávněná a nesmysIná. Do řešení vzniklého dilematu a hledání jiného ekonomického systému se v situaci pohodlné „prosperity" nechce. Obcházení tohoto rozporu je však "strkáním hlavy do písku". Růstová tržní ekonomika není cestou vedoucí $\mathrm{k}$ cíli. Jak má náš život ve světě ekonomických vztahů vypadat? I na tuto otázku můžeme hledat odpověd’ v Bibli.

\subsection{Př́íčiny krize}

Kdo za současný stav životního prostředí může? Najít vyčerpávající odpověd' asi není možné - pokud se nespokojíme s jednoduchou, pravdivou, biblicky založenou odpovědí, že jde o di̊sledek lidského hř́chu. Totéž, avšak z nenáboženského pohledu, říká René Dubos (1980), když poukazuje na to, že k environmentálním problémům dochází tehdy, když patričně vzrostl počet obyvatel a technické možnosti člověka, takže lidstvo "má na to", aby přírodu poničilo. Nicméně stojí za to při hledání příčin environmentální krize pokračovat na jemnější rozlišovací úroveň; neměli bychom při tom zcela pominout nikoli ojedinělé tvrzení, že za degradaci životního prostředí může křestanství.

$\mathrm{S}$ bezohledným nakládáním $\mathrm{s}$ životním prostředím se výrazně setkáváme $\mathrm{v}$ technicky silné euroamerické civilizaci. Ta se rozvinula $v$ tzv. křest́anském prostředí, avšak je více produktem ateistického osvícenství než skutečného křestanství. Llyn White (1967) při své kritice křestáanství jako zdroje myšlení směřujícího ke ztrátě vztahu k prostředí jde hlouběji. Uvědomuje si, že mnohá místní pohanská předkřestáanská náboženství často situovala svá božstva do prvků prírody - do stromů, do skal apod. Tím byl podporován určitý vztah úcty a bázně. Člověk bohatost př́rody nepřijímal jako samozřejmost, s níž Ize libovolně nakládat. Křestanství tuto deifikaci prírodních objektů ukončilo. Llyn White to považuje za chybu (White, 1967; Granberg-Michaelson 1988). Z křestanského hlediska zde př́mo chyba přirozeně neleží. Přírodní objekty nejsou sídlem božstev, avšak celá príroda je Božím dílem, krásným a dobrým, svěřeným člověku k užívání a k opatrování. Díky svědectví Písma o tom, kdo je Bůh (Hospodin, Jahve), je tato skutečnost daleko lepším základem pro vytváření vztahu mezi člověkem a celým stvořením, než by mohl být jakýkoli pohanský kult. Žel, teologie stvoření nejen v minulosti, nýbrž i v současnosti stojí stranou výraznějšího zájmu teologů a kazatelů, což znamená, že něco podstatného v našem kázání evangelia chybí. Tento nezájem se promítá i do různých cyklů výběru biblických perikop pro jednotlivá nedělní kázání.

Minulé století nastolilo otázku slučitelnosti vědy a víry. Stále není málo těch lidí, jimž možnosti rozumového poznání zakrývají přístup k Bohu. Naproti tomu jsou i věřící lidé, kteří jsou ochotni přijmout poznatky vědy jen tehdy, nejsou-li v rozporu s jejich často velice dogmatickým a zkratkovitým chápáním Písma. Dnes se mezi křestany často príímá názor, že oblast víry a oblast vědeckého poznání spolu vůbec nesouvisejí. Tento předpoklad nezávislosti materiálního, vědou poznatelného světa, a skutečností, přijímaných vírou, způsobil, že se do postojů vưči materiálnímu světu nepromítalo to, co je předmětem víry. Produktem karteziánsko-osvícenského myšlení se stalo oddělení světa rozumem poznatelného od skutečností racionálně nepoznatelných a jen vírou přijímaných, které ignoruje, že pravá věda směřuje a slouží k poznání Božího stvoření. Věda je cenným prostředkem umožňujícím člověku plnit jeho poslání, které podle biblického podání mu bylo samým Bohem svěřeno. Stvořený svět je předmětem vědy i víry ${ }^{1}$, víra se na něj dívá z určitého nadhledu, zatímco věda zevnitř. Věda člověku umožňuje prohlubovat vztah $\mathrm{k}$ Božímu stvořitelskému dílu. Na to se v

\footnotetext{
${ }^{1}$ Odpovídá to novozákonnímu učení, že Boží království sice kvalitativně převyšuje tento svět, avšak zároveň je aktuální skutečností, dotýkající se současnosti.
} 
evropské kulturní oblasti zapomíná. Vztahům mezi prírodními vědami a teologií se (zatím) věnuje jen malá pozornost.

Evropa se stává stále méně křestáanskou. Křestáané svému okolí zůstávají dlužni jasné prorocké slovo, $\mathrm{k}$ němuž je víra ve smysluplnost Božího stvoření a v jeho obnovu Kristovým vykupitelským dílem nejen opravňuje, nýbrž i zavazuje a vybízí. Zřetelné označení současnosti „pravým jménem" a varování před nebezpečnými trendy se často daleko zřetelněji ozývá z jiných míst (Lorenz 1990, Meadows 1972). Lorenzových "Osm smrtelných hříchư"z je profétský hlas moudrého vědce, který umí nezávisle myslet. Křestáanskému čtenáři se při čtení této útlé knihy, napsané již v sedmdesátých letech minulého století, avšak u nás vydané až r. 1990, snadno vybaví představa starozákonních proroků, neohroženě kárajících všeobecné počínání svých současníků a poukazujících na to, co by bylo správné.

\subsection{Problém růstu}

Člověk od počátku historie ovlivňoval své prostředí. Mnohá z jeho dřivějších činností by před kritickým hodnocením dnešními ekologickými měřítky neobstála. Víme např., jak na místě lesů se objevovala pole. Víme však také, jak v porovnání s dneškem byla Země málo lidnatá a jak skromné technické prostředky člověk měl k dispozici. Po převážnou dobu své historie si člověk neuvědomoval omezenost prostoru, $v$ němž se pohyboval. Před více než 200 lety anglický duchovní Rev. Thomas Malthus (1798) zřetelně upozornil na skutečnost exponenciálního růstu populace na Zemi, což znamená, že i kdyby zdroje obživy rostly, avšak lineárně, musí príít doba, kdy nebudou stačit. Exponenciální růst populace je logickým důsledkem „přirozeného" předpokladu, že přirůstek populace za jednotkové období je př́mo úměrný velikosti této populace. Exponenciála roste $v$ čase nade všechny meze, a to rychleji než lineární či kterákoli jiná algebraická funkce. Je jasné, že takovýto růst není trvale možný. Předpoklad, že př́růstek je př́mo úměrný velikosti populace, tedy nemůže být v praxi splněn. A skutečně, hovoří proti němu především dvě skutečnosti. První je, že růst se děje na úkor něčeho, nějakého vnějšího prostředí. Dokud je můžeme považovat za "nekonečně velké", pak je zmíněný předpoklad oprávněný, avšak jakmile musíme uvažovat, že s růstem populace se toto prostředí zmenšuje, že růst se děje na úkor něčeho, musíme předpoklad př́mé úměrnosti mezi př́růstkem a velikostí opustit.

Závažnější je druhá námitka proti výchozímu předpokladu. Svět tvoří jeden systém a vše, co na něm probíhá, je vzájemně vázáno. Vývoj populace závisí na mnoha faktorech, které jsou opět mezi sebou provázány a stavem populace ovlivněny. T. Malthus upozornil na omezení růstu v souvislosti s růstem počtu lidí na Zemi. Avšak je jasné, že s existencí člověka jsou svázány další veličiny, jež rovněž v čase rostou, často i daleko rychleji než populace jako taková, a jejichž vnější kvantitativní omezení leží možná takřka na dosah. Jde např. o spotřebu surovin či prostor $\mathrm{k}$ deponování produktů lidské činnosti. Vytvoření adekvátního matematického modelu se stává podstatně složitějším a je jasné, že do něho nelze zahrnout všechny vazby a zákonitosti, a to již proto, že naše poznání světa nikdy není úplné. Analytické řešení vytvořených matematických modelů, které obsahují i četné nelineární závislosti, zpravidla není možné, a proto neocenitelnou pomocí se stává modelování a numerické výpočty na počítači.

Problém růstu se netýká jen populace. Uvažujme prakticky libovolnou ekonomickou statistiku. Místní a časová porovnatelnost údajů vyjadřovaných v peněžních jednotkách je

\footnotetext{
${ }^{2}$ K. Lorenz žil v katolickém Rakousku a Bavorsku. Lze se domnívat, že v prostředí ryze protestantském by knihu nazval "Osm smrtelných projevů lidského hříchu” či nějak podobně.
} 
problematická. Ekonomické statistiky však zahrnují i tzv. naturální ukazatele, jako např. vývoj produkce energie (zajímá nás zde především produkce energie $v$ úhrnu, nikoli vztažená na osobu), celosvětovou těžbu jednotlivých surovin apod. Kromě absolutních hodnot se u těchto ukazatelů obvykle uvádí roční přirůstek v procentech, jehož sledování souvisí $\mathrm{s}$ apriorním předpokladem exponenciálního růstu hodnot těchto ukazatelů.

\subsection{Trvale udržitelný rozvoj}

Malthusovy myšlenky promítnuté do myšlení druhé poloviny 20. století nacházíme ve studiích Římského klubu (zal. 1968), zpracovaných především Donellou a Denisem Meadowsovými a Jørgenem Randersem. První a snad nejznámější z nich, Meze růstu (Meadows 1972) směřuje k ideji trvale udržitelného zpưsobu života, pro nějž je charakteristický stabilní (dynamicky) rovnovážný stav. V něm musejí zůstat konstantními (s možnými výchylkami na obě strany) populace a kapitál. Ten zahrnuje i všechny neobnovitelné prírodní zdroje, mezi něž patří i naprostá většina dnešních zdrojů energetických. Je tedy nutná totální změna světové energetické politiky. Činnosti, jež nedegradují prostředí a nevyžadují velké materiálové toky, mohou neomezeně probíhat. Vzdělání, umění, hudba, náboženství, atletika ( $v$ čistém, nezkomercionalizovaném smyslu) a sociální interakce tedy mohou vzkvétat.

Technický pokrok je a bude i ve stavu rovnováhy nutný. Měl by se týkat především efektivní energetiky (využití tzv. alternativních zdrojů energie, radikální omezení energetických ztrát), recyklace materiálu, prodloužení životnosti výrobků, medicíny (včetně antikoncepce) apod. Cílový rovnovážný stav tedy rozhodně neznamená stagnaci rozvoje člověka. Jde však o to, že rozvoj nesmí být spojován s kvantitativním (materiálním) růstem. V historicky významné "Zprávě G.H.Brundtlandové" (Brundtland 1987) se vymezuje trvale udržitelný rozvoj jako takový způsob rozvoje, který "uspokojuje potřeby prítomnosti, aniž by oslaboval možnosti budoucích generací naplňovat jejich potřeby". Aby nedocházelo k nedorozumění způsobenému nesprávným chápáním rozvoje jako materiálního růstu, hovořivá se někdy raději o "trvale udržitelném životě" či o "trvale udržitelném způsobu života". Protože však život nepřipouští stagnaci, „udržitelnost" či "trvalá udržitelnost" (angl. sustainibility) života je bez určité formy rozvoje nemyslitelná; musí ovšem jít o rozvoj v duchovní (kulturní, nemateriální) dimenzi.

Rozdělení světa na chudou a bohatou část považují členové Meadowsova teamu za velice závažnou skutečnost. Do svého počítačového modelu je však $z$ dříve uvedených důvodů nemohli hlouběji začlenit. Později byl vytvořen podrobnější počítačový model vývoje světa, přihližející k ekonomickým, kulturním a sociálním rozdílům mezi jednotlivými částmi světa. Stal se základem další zprávy Římskému klubu; jeho závěry, publikované $v$ knize Mankind at the Turning Point (Mesarovic 1974), jsou v souladu s Meadowsovými výsledky.

Autoři Mezí růstu ve své knize Překročení mezí (Meadows 1997) s odstupem dvou desetiletí zhodnotili své profétské dílo z r. 1972 pod zorným úhlem světového vývoje v poslední čtvrtině dvacátého století. Opět se zde věnují možné další cestě světa a lidstva, přičemž jejich metodika díky velkému pokroku počítačové techniky dává nyní daleko větší možnosti. O závažnosti knihy, $v$ originále vydané $v$ roce 1992 , svědčí $i$ to, že úvodní slovo $\mathrm{k}$ němu napsal Jan Tinbergen, jeden z dvojice prvních laureátů Nobelovy ceny za ekonomii.

„Překročení mezí patří mezi základní literaturu z oblasti vztahu člověka a životního prostředí. Jako $v$ naprosté většině knih takto orientovaných je i zde zřetelný důraz na nutnost změnit zpưsob života a príímání hodnot. Nenajdeme zde však ani náznak jakékoli skepse vưči technice či vưči lidskému poznání vůbec. Naopak, kniha zřetelně apeluje k širokému a hlubokému studiu, $\mathrm{k}$ rozvoji vědy a techniky, $\mathrm{k}$ hledání cest, jak při dnešním (a zatím stále rostoucím) počtu obyvatel Země, který by byl důstojný pro všechny lidi a přitom šetrný $k$ bohatství naší planety. 


\subsection{Jednadvacáté století}

Dnes už vědomí, že na našem vztahu k životnímu prostředí záleží, je celkem běžné. Zateplují se budovy a řeší se hospodaření vodou v nich, třídí se odpad, města investují do hromadné dopravy s cílem omezit individuální automobilismus. Nicméně základní postoj člověka se nemění. Místo uskromňování nároky rostou. Přibývá leteckých spojů, stavějí se další silnice, rozšiřují se životnímu prostředí nepřátelské sportovní aktivity (např. sjezdové lyžování), mnohé výrobky mají velmi krátkou životnost, často kvưli tzv. „morálnímu opotřebení", atd.

Křest'ané si více než dříve uvědomují, že jejich Biblí a vírou motivovaný postoj může mít vliv i na všeobecně přijímaný životní styl. Vznikají různé křestanské environmentální iniciativy, at' už v rámci jednotlivých křest́anských církví (např. Poradní odbor pro otázky životního prostředí při Synodní radě Českobratrské církve evangelické) či nadcírkevní (Evropská křestáanská environmentální sít - ECEN, v ČR působící jako Česká křestáanská environmentální sít' - ČKES, A Rocha - křestáané chrání přírodu, Ekologická sekce České křest'anské akademie), vycházejí příručky zaměřené na křest́ansky motivovaný životnímu prostředí příznivý styl života (např. Nováček 1998, Szőlős 2001, Birch-Vischer 2007, ČKES 2012) i na křestáanskou environmentální výchovu (Loosli-Amstutz 2014, Světlík 2003, Jančaříková 2015). Na svatodušní neděli 2015 vydal papež František encykliku Laudato si', která svým dosahem překračuje hranice Římskokatolické církve a volá křestáany k environmentální odpovědnosti, přičemž se nevyhýbá sociálním, politickým ani ekonomickým otázkám (František 2015).

V následujících kapitolách (2 až 5) se vydáme na „ekologickou procházku" Biblí. Uvidíme, že pro náš vztah k životnímu prostředí má Bible mnoho co říci.

\section{Stvoření}

\subsection{Ráj}

Prvních 11 kapitol Písma je hlubokou alegorií, která má vytvářet vztah mezi člověkem a Stvořitelem a zároveň i mezi člověkem a ostatním stvořením. Dnes snad už ani ti nejfundamentalističtější křest́ané či Židé je nepřijímají jako doklad o tom, že by mezi vznikem vesmíru a počátkem života člověka na zemi uplynulo mezi 120 a 144 hodinami; je známo, že např. biblicky fundamentalističtí Svědci Jehovovi rozumějí dnu v líčení Gn. 1 jako označení pro 1000 let, a tak interval 6 dnů (144 hodin) se prodlužuje na 2,2 mil. dnů (52,6 mil. hodin); to ovšem stále pro většinu současných vědců je nepřijatelné. Na druhé straně pro mnohé liberálně orientované čtenáře Bible jsou její první kapitoly jen mýtem, majícím co říci jen pro vztah mezi člověkem a Bohem, avšak zcela irelevantním pro vše, co se týká ostatního stvoření. Extrémním biblickým fundamentalistům (tento termín necht́ zde není přijímán s negativním morálním zabarvením) i extrémním liberálům tak zůstává skryta ona nesmírná hloubka biblické zvěsti o stvoření, které není jen souhrnem druhů, nýbrž v němž od počátku existují hluboké vztahy a vazby, o stvoření, které je jedním harmonickým celkem.

Několikrát čteme v prvním kapitole Písma, že to, co Bůh stvořil, bylo dobré (Gn 1,4.10.12.18.21.25.31). A po ukončení tvoření materiálního, smysly dostupného světa, viděl Bůh, že co stvořil, bylo velmi dobré. Biblické líčení stvoření světa (kosmu, vesmíru) zde však nekončí. Po šesti dnech následoval den sedmý - den odpočinutí Hospodinova. Antropomorficky řečeno, sedmý den se Bůh radoval z díla stvoření. Bủh stvořil svět, aby měl radost. 
Svět je stvořen pro Boží slávu. Člověkem vrcholí materiální tvoření, avšak člověk není středem či smyslem stvoření. Tím zůstává Bůh sám³.

Přesto však člověk mezi stvořením má určité mimořádné postavení, či spiše mimořádnou úlohu: Má o stvoření pečovat a smí je uživat (Gn 1,27.28; 2,15). Ostatní stvoření je tak pro člověka zdrojem odpovědnosti, tedy závazkem, a zároveň darem, daným k užívání a sdílení s druhými, nikoli k volnému nakládání - Země je a zůstává Hospodinovým vlastnictvím (Ž 24,1). Celé stvoření je pro člověka důležité. $K$ jeho plnosti patří vztah, který si člověk k němu vytváří tím, že je pojmenovává (Gn 2,20).

Bezděky hovoříváme na jedné straně o člověku a na straně druhé o ostatním stvoření. Zamysleme se nad touto vyjadřovací konvencí a použijme při tom jazyk teorie systémů. Stvoření tvoří jeden, velký, složitý systém. Ten Ize nejrozmanitějšími vhodnými i nevhodnými způsoby dekomponovat, tedy rozložit na podsystémy. Kritéria dekompozice teoreticky sice mohou být libovolná, avšak rozumné, smysluplné je sledovat při tom určité cíle, přičemž by mezi ně měly patřit požadavky, aby

(1) dekompozice zjednodušila možnosti popisu systému,

(2) jednotlivé podsystémy byly co nejvíce autonomní (samostatné).

Praxe hovořit o člověku a "ostatním stvoření" je vhodná a přirozená z hlediska prvního kritéria, zatímco druhé kritérium splněno není - vazby člověka s jeho systémovým okolím, s "ostatním stvořením", jinými slovy - se „životním prostředím" jsou velice silné a spletité a navzdory růstu našeho poznání stále o nich víme přiliš málo. Jestliže tedy mluvíme o "člověku" a o "ostatním stvoření", děláme tak pro usnadnění popisu z našeho lidského hlediska a rozhodně tím nepomíjíme složitost vazeb, jimiž je člověk do celého úžasného systému stvoření včleněn.

\subsection{Potopa}

Po líčení rajského období před prvním hříchem hovoří Geneze o prvním hříchu a jeho důsledcích, z nichž nejvýraznější je potopa. Tento príběh o Božím trestu jako důsledku lidského hříchu a záchraně Noemovy rodiny i dalších biologických druhů prostřednictvím korábu svědčí, že

a) lidský hřích se týká i „ostatního stvoření", ničí kvalitu života jako takového,

b) Bohu na celém stvoření skutečně záleží.

\subsection{Věž v Bábel}

Biblická prehistorie končí príběhem stojícím mimo adamovsko-abrahámovskou linii stavbou věže $v$ Bábel. Jako čtenáři jsme zde uvedeni do již poměrně zalidněné země, kde si lidé vzájemně rozumějí - používají tentýž jazyk. $V$ této vzácné jednotě podlehnou podobnému svodu jako první lidé v ráji - chtějí být jako Bůh. Aby tuto svou hříšnou touhu uskutečnili, rozhodnou se pro stavbu vysoké věže, která bude sahat až $\mathrm{k}$ nebesům. Vynaloží ohromné úsilí, aby své velikášství ukojili. Avšak poslední slovo nemá člověk, nýbrž Bủh. Lidé

\footnotetext{
${ }^{3}$ Stvoření v 7 dnech vyjadřuje gradaci Božího tvůrčího díla. Sdělení knihy Genesis rozhodně neznamená, že by Boží tvưrčí dílo bylo v minulosti ukončeno. Vždyt' k němu patří i vykoupení skrze Ježíše Krista. A Ježíš svědčí, že Bůh je stále při díle $(J 5,17)$. Samu budoucnost lidstva je vhodné chápat jako otevřenou (srov. kap. 7). Biblický čas (KAIROS) nelze redukovat do orientované přímky (CHRONOS).
} 
ztrácejí možnost se domluvit, jejich řeči jsou rozděleny. Nemožnost a neschopnost vzájemné komunikace je důsledek lidského hř́chu, který dnes pocitúujeme snad na každém kroku. Projevuje se markantně i v tzv. "tragédii občiny"

\subsection{Teologie stvoření}

Na závěr podkapitoly věnované stvoření poznamenejme, že teologie stvoření má pro vztah člověka k životnímu prostředí zásadní důležitost. Ta se však nevyčerpává studiem prvních 11 biblických kapitol. Kromě nich pohled na Boží stvořitelské dílo vyjadřují mnohé Žalmy (např. Ž 24,1), prolog k Janovu evangeliu $(\mathrm{J} 1,1-5)$ aj. Žel, teologie stvoření je zatím $v$ teologických kruzích poměrně opomíjená; podrobně a v širokých souvislostech se jí věnuje J. Moltmann (1985). Z českých teologů se jí angažovaně věnoval Jan Heller (1994, 2000)

\section{Mojžíšův zákon}

\subsection{Mana}

Druhá až pátá kniha Mojžíšova nám přibližuji Hospodinovu péči o Jeho vyvolený, avšak znovu a znovu klesající a hřešící lid. Známým dokladem Božího zájmu o putující potomky Jákobovy je seslání many (Ex 16). Lidé nemusejí trpět hladem. Bůh jim zajistí pokrm manu. Ta jim ovšem nepřilétne až do úst. Je třeba vynaložit určité úsilí, určitou práci a manu sbírat. Je jí dost pro všechny. Avšak ti chamtivci, kteří si naberou many více, než kolik potřebovali, se dočkají nakonec jen odporného zápachu zkažené potraviny.

Z príběhu o seslání many plynou závažné aktuální důsledky, spadající do oblasti ekonomie a týkající se sdílení Božích darů, jež můžeme sekulárně nazvat bohatstvím planety Země či prostě prírodními zdroji. Ekonomická teorie hovořivá o třech zdrojích bohatství, jimž jsou

1. př́rodní zdroje,

2. lidská práce,

3. kapitál.

Kapitál je zdrojem bohatství vytvořeným $v$ minulosti. Primárními, původními zdroji jsou zdroje prírodní a práce. Pro pouští putující Izraelity byla mana přírodním zdrojem a její sbírání prací. Obojí bylo nutné, přesto však hlavní byla mana jako taková. A na ni měli stejný nárok všichni. Někteři pracovali méně a sebrali si jí třeba jen tolik, aby se najedli do polosyta, jiní pracovali více a mohli se najíst dosyta. To i ono bylo $v$ pořádku. Avšak špatně si vedli ti, kdo pracovali ještě více a nabrali si nad svoje potřeby. $Z$ oné many navíc nejen že nic pozitivního neměli, nýbrž museli ve svých stanech udělat určité úklidové práce navíc (odklidit zkaženou manu).

Současná ekonomika vše přepočítává na peníze, a tak nezná oddělené rozdělování př́rodních zdrojů a výsledků lidské práce. Na poušti bylo many dost pro potřeby všech. Dnešní člověk však vlastně ani neví, co skutečně potřebuje. Běžná představa o vlastnictví zdrojů, tedy vzácných Božích darů, nevyhovuje teologicky ani eticky ${ }^{4}$. Současná ekonomická

\footnotetext{
${ }^{4}$ Existují legislativní dokumenty, které tuto situaci uspokojivě řeší. Např. v ústavě SRN v čl. 14, odst.

2 stojí: Vlastnictví zavazuje. Jeho užívání má sloužit zároveň k dobru celku.
} 
praxe vede $\mathrm{k}$ nešetrnému nakládání $\mathrm{s}$ nimi, spojenému s podceňováním práv a potřeb budoucích generací. Proto by mělo být morální povinností křestáanských teoretických ekonomů směřovat tímto směrem a jít cestou, kterou otevřeli E.F. Schumacher (1978) a H. Daly (1973) a jíž z našich současných ekonomů jde např. L. Mlčoch (Pokoj a dobro 2000).

\subsection{Desatero}

Člověkem způsobené škody na životním prostředí mají kořen v neposlušnosti Božímu zákonu. Můžeme si to ilustrovat i na sinajském Desateru (Ex 20,2-17). V naší civilizaci se stalo běžným uctívat hrubý domácí produkt s jeho růstem (jehož věčnost novodobí "kněži" - „ekonomové" navzdory prírodním zákonům nekompromisně postulují), tzv. liberální principy, "svobodný" trh, růst firem, auta atd. S těmito kultovními objekty zpravidla souvisí bezohledný kořistnický př́stup k prírodě (srov. kap. 4). Jiní bohové se tak dostávají na místo, které patří jen Hospodinu (Ex 20,3). Silná materiální orientace se promítá i do materiálních nároků v době "aktivního odpočinku" - nákladné cesty, náročné sportovní vybavení (včetně prostoru k provozování sportu - mnohá hřiště mají více méně charakter pouště), složitá audiovizuální technika. $V$ této situaci se ztrácí pravý smysl sedmého dne, dne odpočinutí, dne, kdy je člověk směrován k odpočinutí od všední práce, k plnému prožívání lidství - v obecenství s Bohem a s druhými lidmi. Křestáan není vázán židovskými pravidly prožívání "dne sobotního", avšak to neznamená, že by měl negovat motivy, na nichž po mnohá staletí po Kristu lidé Staré smlouvy stavějí svá pravidla života. Svěcení dne Hospodinova odpočinutí (Ex 20,8-10) s prožíváním integrity jeho tvưrčího díla vede $\mathrm{k}$ hlubšímu prožitku přináležitosti k celému stvoření (Fromm 1992).

Často bývá připomínán výrok Mahátmá Gándhího "Země je dostatečně bohatá pro potřeby každého, nikoli však pro chamtivost každého". Člověk euroamerické civilizace si bere z bohatství země více, než kolik by mu právem náleželo, než kolik odpovídá jeho skutečným potřebám. Počíná si tak jak na úkor lidí z jiných kultur, tak na úkor příštích generací. Bere si, co mu nenáleží. Při tom přikázání "Nepokradeš" (Ex 20,15) je tak jasné a srozumitelné! Avšak nejen že se nedělíme o vzácné Boží dary a tím okrádáme své bližní. Naše počínání může znamenat překročení přikázání „Nezabiješ" (Ex 20,13), jak jsme na př́kladě možných důsledků naznačili v čl. 1.2.

Zdrojem chtění mít více, tedy větších materiálních nároků, znamenajících větší zatížení přírody, bývá často skutečnost, že to či ono má někdo druhý. Závist stupňuje lidské nároky. A tak věrnost poslednímu přikázání "Nepožádáš" (Ex 20,17) by měla být plněna nejen proto, že je to Boží vůle, že upravuje bezprostřední vztahy mezi lidmi, nýbrž má i výrazný žádoucí dopad na životní prostředí.

\subsection{Restituční roky}

Ve 25. kapitole Levitiku se zavádějí dva vzájemně těsně související instituty, navazující na přikázání světit sedmý den - sabatikální sedmý rok a jubilejní (milostivý) 50. rok. Sabatikální rok zřejmě má zamezit př́lišnému vyčerpávání země, a to nejen fyzicky, nýbrž i morálně, jako připomenutí, že člověk nemá právo ze země vydobývat technicky možné maximum. U jubilejního padesátého roku převládá právně ekonomický důraz. Probíhá restituce vlastnických vztahů, návrat do původního stavu. Toto Zákonem diktované obnovování původního stavu (které ovšem $v$ praxi zřejmě nebylo př́liš respektováno) vede $\mathrm{k}$ zamezení jednosměrných vývojových trendů směřujících ke kumulaci bohatství, která by mohla znamenat nekontrolované zacházení s př́rodními zdroji, jejich nespravedlivé dělení a následné nadměrné čerpání, jak to známe z moderní ekonomiky. 


\section{Starozákonní proroci}

\subsection{Modlářství}

Izraelský národ na cestě dějinami od samého počátku mohl prožívat Stvořitelův zájem a působení a při tom si hluboce uvědomovat svou závislost na Něm. Přesto však nebyl Hospodinu věrný a často hřešil, především porušováním prvního přikázání. Božstva okolních národů pro něj měla jakousi zvláštní přitažlivost. Boží lid, povolaný k výlučnému uctívání Hospodina, na straně jedné, a jeho okolí se svou pohanskou kultovní praxí na straně druhé - to ovšem není specifikum situace starozákonního Izraele. Dnešní postavení církve ve světě je v mnohém velmi podobné a uctívání cizích bohů může mít fatální důsledky, a to nejen pro církev. Izraelský národ v praxi nerespektoval ustanovení Mojžíšova Zákona. Tato nevěrnost Hospodinu, jedinému a jedinečnému Bohu, je ve SZ, zvláště v Prorocích, bohatě dokumentována. Prorocká slova zaměřená proti modlářství, proti přejímání kultické praxe okolních národů a proti klanění se jejich bohům mají co říci i nám, křestáanům - Božímu lidu Nové smlouvy - na počátku třetího tisíciletí po Kristu.

Na rozdíl od lidu Staré Smlouvy žije Církev v rozptýlení. Tím však silnější je pokušení nechat se asimilovat, ztrácet svou identitu, sloužit cizím bohům, moderně řečeno "prijímat cizí hodnotové stupnice". A životní hodnoty, které zdůrazňuje Ježíš, se výrazně liší od hodnot všeobecně přijímaných dnešním běžným člověkem. Rozvinutá kapitalistická společnost se opírá o lidskou touhu mít, vlastnit co nejvíce a stále novější, modernější a dokonalejší předměty, jejichž nabídka převyšuje poptávku. Reklama až zákeřně nutí zkoušet a používat stále další výrobky. Zde už nejde o životní potřeby, nýbrž o něco navíc, něco, co člověk nepotřebuje, avšak tím, že tomu věnuje svůj zájem, své úsilí, větší či menší část své osobnosti, se mu to stává předmětem kultu.

$\checkmark$ knize proroka Izajáše (Iz 44,9-20) čteme o muži, který získal značné množství dřeva. Použil je $\mathrm{k}$ topení, $\mathrm{k}$ vaření, a ještě mu zbylo. Měl ho více, než potřeboval. A tak $z$ toho, co bylo navíc, vyrobil modlu a té se klaněl. Souvislost mezi nadměrným vlastnictvím a modloslužbou, na kterou Izajáš ukazuje, zůstává stále aktuální - a my, Evropané na konci 20. století, bychom si jí měli být hodně vědomi. Tesané modly byly nahrazeny moderními modely aut, dalekými zahraničními cestami, cennými papíry a dalšími součástmi našeho způsobu života. Základní tón starozákonních proroků - varování před modloslužbou - je tak živý i pro současnou evropskou kulturu. Materiální bohatství, majetek přináší pokušení k modloslužbě (Daly 1973).

\subsection{Prosperita za Ozeáše}

Materiální dostatek, dnes nazývaný prosperitou, byl charakteristický pro Izrael v době působení proroka Ozeáše. Ten $\mathrm{k}$ důraznému varování před nevěrností Hospodinu a jejími hroznými důsledky používal nejen slova, nýbrž i originální mimoverbální prostředky. Přitom však nezůstával jen u ohlašování soudu, nýbrž také zvěstoval naději pro ty, kdo se opravdově obrátí k Hospodinu. Izrael si chtěl vlastními prostředky zajistit trvalost příznivého ekonomického stavu. Viděl počínání okolních národů, jejich úsilí naklonit si svými obět́mi Baala, pohanského boha úrodnosti a prosperity. Izraelité se nechali strhnout. Místo aby se obraceli k Hospodinu a očekávali Jeho nové věci, snažili se vše vzít do své režie a zajistit trvalost stavu charakterizovaného materiálním dostatkem. Neuvědomovali si, a zřejmě si ani nechtěli uvědomit, že onen stávající stav, z hlediska hmotného zajištění př́ijemný a žádoucí, se v jiných dimenzích projevuje jako zcela nemorální a neudržitelný. A začátek 4. kapitoly Ozeášova proroctví $(\mathrm{Oz} 4,1-3)$ svědčí o tom, že zvrácené lidské vztahy se promítají do celého stvoření. 
Ve 2. kapitole Ozeášova proroctví je nevěrný izraelský lid přirovnáván k nevěrné ženě, která zapomíná či spíše si nechce připustit, že co má - obilí, mošt i čerstvý olej, má od skutečného manžela, tedy od Hospodina. On ji zahrnul zlatem a stř́brem. Nevěrnou ženou zobrazený lid si z toho udělal Baala. Hospodin však není pasívní Bůh nacházející se jen někde mimo svět. Danou situaci vidí a bude jednat. Řešit věci ve vlastní režii, bez Hospodina, se z Ozeášova hlediska jeví jak zcela pošetilé.

Selhání Božího lidu $v$ době Ozeášově nebylo prvním ani posledním. Přesto $k$ tomuto klesajícímu, hřešícímu a od cesty spravedlnosti se vzdalujícímu lidu prorokovým prostřednictvím zaznívají výmluvně varovná aktuální Hospodinova slova. A jsou aktuální i pro nás, nebot' jak obracení se k pohanským bohům, tak spokojenost s ekonomickým systémem, vyjádřená snahou zachovat stávající stav $v$ jeho dynamice, byly charakteristické nejen pro dobu Ozeášova působení $v$ severním Izraeli za Jarobeáma II., nýbrž i pro naši současnou euroamerickou civilizaci. Kult ekonomických paradigmat, rozvíjejících se od doby osvícenství, stále kvete a na jeho oltář se přinášejí nejrozmanitější oběti. Je paradoxní, že ač s posledními dvěma sty lety lidské historie bývá spojena představa o zvýšeném důrazu na rozum a vědecké poznání, "ekonomické" myšlení, konstituované v tomto období, zcela ignoruje poznatky prírodních věd o omezenosti prostoru, vyčerpatelnosti zdrojů a nevratnosti reálných procesů $v$ prírodě. Tyto poznatky jsou obětovány na oltář božstva naší civilizace, především jejího ekonomického systému.

Ozeáš ukazuje, k jakým hrozným důsledkům směřuje odpadnutí od Hospodina, vzetí věcí do svých rukou, spojené s kultem Baala - mamonu. Přitom však nezůstává u slova soudu. Po něm následuje slovo naděje $(\mathrm{Oz} 2,16-25)^{5}$. Prorok přitom není analytik ani prognostik. Jeho slova však nejsou ani uměleckým dílem líčícím jakýsi neskutečný obraz toho, co bude. Jsou závažnou výzvou burcující lid k akci, ke změně myšlení a jednání. Navzdory př́znivým ekonomickým ukazatelům byla situace Izraele zlá. Byla zlá proto, že byl narušen jeho vztah k Hospodinu. Lidé Ho škrtli ze svého světa. Neobraceli se k Němu, nýbrž spoléhali na Baala a na své síly. U vědomí těchto skutečností cítíme, jak ona archaická, místy nám těžko srozumitelná Ozeášova řeč má říci mnohé naší současnosti, kdy jak narušené vztahy mezi lidmi, tak narušené vztahy $\mathrm{k}$ přírodě, $\mathrm{k}$ životnímu prostředí jsou důsledkem narušení vztahu člověka k Bohu. Člověk se zhlíží v růstu hrubého domácího produktu. Vytvořil si ekonomický systém, v němž nejvyšší a vlastně univerzální hodnotou jsou peníze - mamon - novodobý Baal. Tomu vše podřizuje a jeho uctívá. Drogy, kriminalita, prostituce, snížení tělesné odolnosti lidí, genetické a fyziologické změny, nemocná př́roda, jedovaté ovzduší to jsou průvodní jevy moderní civilizace, to jsou oběti přinášené na Baalův oltář. Jak absurdní ve světle prorokových slov je takové směřování společnosti! výše zmíněné Ozeášovo slovo naděje, používající krásný eschatologický obraz, je výzvou ke změně, k obrácení se k Hospodinu. Nejde o nějaký obrat na místě, nýbrž o vykročení $k$ Jeho budoucnosti. Dnes slova starozákonních proroků můžeme vnímat skrze novozákonní učení. "Ne každý, kdo mi říká 'Pane, Pane', vejde do království nebeského; ale ten, kdo činí vůli mého Otce v nebesích" (Mt 7,21), ríká Ježíš. Člověk je stvořen k Božímu obrazu. Pohyb, tvưrčí aktivita nedílně patří k lidství. Hodnoty, které jsou skutečnými hodnotami před Boží tváŕí, leží mimo současné ekonomické kategorie. Svědčí o tom Písmo sv., v nejkoncentrovanější formě známé Ježíšovo Kázání na hoře (Mt 5-7; srov. čl. 5.1 a 5.2).

${ }^{5}$ Číslování veršů podle ekumenického překladu 


\subsection{Trest a naděje}

Používání stupnice hodnot, která je v rozporu s Božím Slovem, s evangeliem, je výrazným projevem moderní modloslužby. "Kde je tvůj poklad, tam bude i tvé srdce," (Mt $6,21)$ ř́ká Ježíš. Ty hodnoty, které On v Kázání na hoře zdůrazňuje, se nejen diametrálně liší od praxe dnešní společnosti, nýbrž znamenaly revoluční změnu myšlení i ve starověké Palestině. Běžný je názor, že budoucnost patří těm, kdo se dovedou prosadit, kdo mají intelektuální schopnosti i dostatek osobní průbojnosti a drzosti. Avšak Ježíš v souladu s poselstvím starozákonních proroků spojuje budoucnost Země s tichými, či pokornými, mírnými, nenásilnými - jak můžeme řecké př́davné jméno 'prays' z Jeho třetího blahoslavenství přeložit.

Trestem za opakující se hřích se stal starozákonnímu lidu exil. Tam však jeho historie nekončí. Snad zřetelněji než kdy dříve mohli Židé slyšet prorocké slovo naděje $v$ Babylóně. Síla Boží věrnosti, Jeho lásky a slitování je tak velká, tak mocná, že převyšuje naši lidskou nevěrnost. Juda se vrátil ze zajetí s novým zájmem o Boží zákon. A po čtyřech a pưl staletích se v tomto národě narodil Ježíš Kristus, Spasitel světa. $V$ historii Božího lidu se otevřela nová epocha.

Starozákonním prorockým textům můžeme rozumět ve vztahu ke konkrétním skutečnostem $v$ historii izraelského národa: Nevěrnost Hospodinu $v$ době rozděleného království, exil jako trest, návrat $z$ exilu jako projev Božího slitování a milosrdenství. Jejich smysl je však podstatně obecnější. Hospodinu nesmírně záleželo na tom, aby Jeho lid nehřešil, aby se neuchyloval k modloslužbě. Navzdory všem jeho pokleskům a pádům Boží láska a milosrdenství vítězí a překrývá lidský hřích.

\subsection{Modloslužba oděná do ekonomických pojmů}

Výzvy starozákonních proroků, které jsme uvedli, směřují na první pohled především do oblasti ekonomické. Ekologie ${ }^{6}$ je $v$ nich ovšem také, byt́ nepř́mo. Lidská touha mít co nejvíce, na níž vlastně staví "moderní ekonomika, je totiž jednou z hlavních př́čin vážného narušení životního prostředí. Důsledkem kultu moderního Baala - mamonu - je násilí vůči celému stvoření, a tedy i vưči prírodě. Pohled na dnešní ekonomiku opřený o svědectví Písma vede $\mathrm{k}$ pokání nad tím, jak moc inklinujeme $\mathrm{k}$ modloslužbě, proti níž tak nesmlouvavě kázali starozákonní proroci. Americký ekonom Herman Daly napsal: „Dnes již nemluvíme o klanění se modlám. Místo nich máme ohavnost zvanou 'hrubý domácí produkt', místo klanění 'růst' či 'maximalizaci'. Modla se stala abstraktnější a její uctívání je více technické než osobní. Avšak modlářství zůstává modlářstvím - a my voláme $\mathrm{k}$ rostoucí nadhodnotě: 'Vysvobod' mne, nebot' ty jsi můj bůh'." Dalyho slova, citovaná z předmluvy ke sborníku ekonomických statí (Daly 1973), jsou jedním z dokladů, jak slova starozákonních proroků, namírená proti modloslužbě, hovoří i k nám. Pánu Bohu velice záleží na tom, aby Jeho lid nehřešil, aby nesloužil cizím bohům. Navzdory našemu hříchu má Hospodin budoucnost ve svých rukou. A na rozdíl od lidu Staré Smlouvy dnes víme, že Ježíš Kristus přišel, aby nás přivedl k Bohu. Jeho obětí byla překonána kletba hříchu. $Z$ celého Zákona On jako největší zdůraznil dvě přikázání, přikázání lásky k Bohu a lásky k bližnímu. Milovat Hospodina cele - i celou myslí a silou - to znamená usilovat o to vyvarovat se hříchu, nesloužit cizím bohům. Je to Jeho milost, že dává lidu Nové Smlouvy poslání být zemi tolik potřebou solí, být světu tolik žádoucím světlem. Poslání, které Ize plnit v síle Ježíše Krista.

${ }^{6}$ Pod ekologií budeme $v$ tomto článku rozumět i environmentalistiku. 


\section{5. Životní prostředí v Novém Zákoně}

\subsection{Novozákonní časový horizont}

Ve Starém zákoně člověk poznává Boží vůli. Pro starozákonního člověka je zcela normální předpokládat, že po něm tu bude žít nedohledná řada dalších generací, mezi nimiž budou i jeho potomci. Toto východisko spolu se starozákonní teologií stvoření a s Mojžíšovým Zákonem je již solidním základem pro vztah člověka k životnímu prostředí. To, že se už v biblických dobách nerozvinula nějaká ekologie či environmentalistika, souvisí na jedné straně s nízkým stupněm rozvoje prírodovědného poznání, na straně druhé pak se skutečností, že při malém tehdejším počtu obyvatel a malých technických možnostech bylo možno životní prostředí považovat prakticky za „potenciálně nekonečné", takže dnešní problémy s omezeností zdrojů a prostoru tehdy nebyly.

Nový zákon vznikal během kratší doby. Autoři jeho knih se upírali k druhému Kristovu příchodu, který očekávali velmi brzy. Uspořádání lidských záležitostí se zřetelem k budoucím generacím není v rozporu s novozákonní teologií, avšak leží kdesi mimo proud jejího hlavního zájmu.

S odstupem dvou tisíciletí - tedy doby zhruba dvakrát delší než jaká uplynula mezi Davidovou vládou $v$ ještě nerozděleném Izraeli a pozemským Kristovým životem - vidíme věci jinak. Novozákonní důraz na připravenost na druhý Kristův príchod však v sobě eventualitu dlouhého čekání zahrnuje. Ježíšovo podobenství o deseti pannách či družičkách patří mezi nejznámější (Mt 25,1-13). V něm ty moudré, které jsou posluchačům dávány za vzor, nespoléhaly, že ženich přijde př́liš brzy, tedy nespoléhaly na časovou blízkost očekávaného eschatologického dějinného zvratu. Byly stále, každým okamžikem, na ženichův příchod připraveny, zároveň však při tom počítaly i s možným dlouhým čekáním, znamenajícím trvání stávajícího stavu.

Motiv neustálé připravenosti na Den Hospodinův je pro Nový zákon typický. Jak konečně dvoutisíciletá historie Božího lidu Nové smlouvy ukazuje, neznamená to, že by tento den musel přijít v horizontu lidského života. Známou skutečností je, že v praxi ekonomického rozhodování docházívá ke konfliktu důrazů na dlouhodobé cíle s dưrazy na cíle krátkodobé. Chybějící informace o "absolutním časovém horizontu" vede k vytváření určitých intuitivních předpokladů o jeho blízkosti či odlehlosti. Ty však - viděno novozákonním prizmatem - nejsou nutné. Ekonomické rozhodování se totiž opírá o určitou hierarchii hodnot. Zmíněný konflikt cílů je poplatný všeobecně přijímaným hodnotám. Jak často - z nenáboženského bodu vidění - zdůrazňoval první a poslední československý ministr životního prostředí Josef Vavroušek, tyto hodnoty jako takové nejsou slučitelné s trvale udržitelným zpưsobem života. (Keller 1995, Keller 1996, Vavroušek 1994). Rozpor mezi krátkodobým a dlouhodobým výhledem mizí ve světle Ježíšova učení. Jeho hodnotový systém je v plném souladu s důrazem na neustálou připravenost při plné neinformovanosti o tom, kdy Onen den přijde (Mt 25,13). Správné zacházení s Božím stvořením, přijetí vlastností, s nimiž se pojí Ježíšova blahoslavenství, kterými Kázání na Hoře začíná, je optimální bez ohlednu na časový horizont. Ježíšova etika je jak pro časnost - současnou i budoucí, tak i pro věčnost.

\subsection{Hodnotový systém Kázání na hoře}

Bůh obdařil člověka rozumem. Tento cenný dar se uplatňuje při rozhodování. Racionální rozhodování spočívá ve výběru optimální varianty jednání, tj. takové, s níž je spojen největší užitek. Jistěže mnohdy nelze odhadnout, jaké důsledky to které jednání bude mít, často i pro nedostatek informace, at' už principální či způsobený osobní leností či pohodlností. Proto existují strategie pro rozhodování za rizika, resp. za neurčitosti. Jim se zde věnovat 
nebudeme a obrátíme svou pozornost $\mathrm{k}$ jinému problému souvisejícímu s racionálním rozhodováním, a to $\mathrm{k}$ otázce, co je užitek. $\mathrm{V}$ hospodářské praxi se jím zpravidla rozumí peněžní či penězi vyjádřitelný zisk ${ }^{7}$. Avšak obecně s takovýmto chápáním užitku nevystačíme. Jsou lidé, kteří veškeré své úsilí zaměřují $k$ tvorbě hmotných statků. Jejich život, sice naplněný usilováním, však v podstatě zưstává prázdným. Ježiš ve svém Kázání na hoře se jednoznačně staví proti takovému životnímu postoji (Mt 6,19-21.24-34). I na zcela nenáboženské úrovni existuje určitá shoda, že záleží na pěstování a prohlubování vztahů v rodině a mezi přáteli, že záleží na tom, co člověk prožívá, at' už v oblasti kulturně společenské či ryze osobní. Peníze člověk nevydělává jen $k$ tomu, aby je kumuloval, at' už v peněžní či v materiální formě, nýbrž - a snad především - aby je použil k účelu, který mu pomůže co nejlépe, nejbohatěji, nejplněji žít. A není těžké si uvědomit, že často v tomto smyslu větším přínosem mohou být jednoduché, levné či peníze vůbec nestojící prostředky než prostředky honosné a nákladné.

Po opuštění mantinelů tradiční ekonomiky a s ní spojeného peněžního vyjadřování užitku směřuje racionální rozhodování k maximalizaci jakési subjektivní, na místě a době závisle abstraktní kvantity, jíž lze snad vystihnout poněkud mlhavým českým slovem „blaho", zde přijímaným s kladným morálním nádechem.

Pro každého člověka je užitek závislý na tom, jakou pro něho jednotlivé věci, skutečnosti, stavy, prožitky mají hodnotu; závisí tedy na přijatém hodnotovém systému. I osobní hodnotový systém se mění $v$ čase a závisí na okolnostech - pro unaveného žíznivého poutníka představuje sklenice studené vody větší hodnotu než třeba počítač, který je jinak jeho základním pracovním prostředkem. Přes subjektivnost $v$ názorech na hodnoty existuje pro ně v každé kultuře určitý všeobecně prijímaný a rozmanitými prostředky stabilizovaný konsensus. $V$ našem prostředí $k$ zajištění této stabilizace slouží např. školní vzdělání, hromadné sdělovací prostředky (u nich jde jak o jimi prováděný výběr informací a jejich komentáře k událostem, tak i o samu obsahovou náplň - výběr vzdělávacích a zábavných programů, resp. článků), nejrozmanitější druhy reklamy apod. Protože pro většinu lidí je náš současný západoevropsko-americký systém hlásící se $\mathrm{k}$ ideji neustálého a neomezeného růstu přes svou vnitřní spornost vnímán jako "př́jemný"9, jsou faktory sloužící k jeho stabilizaci většinou prijímány více méně kladně, byt́ jako "nutné zlo" (reklama).

Své hodnotové systémy mají i jiné kultury, byt s postupující "globalizací" se rozdíly mezi nimi zmenšují (srov. Norberg-Hodge 1996). Ježíš Kristus ve svém učení, zejm. právě v Kázání na hoře (Mt 5-7) přináší svůj hodnotový systém, jehož nejvýraznějším rysem je to, že jeho základní hodnotou je láska. Je určen Jeho následovníkům, těm, kteří mají být solí země a světlem světa. Ježíšova blahoslavenství vyjadřují cílové hodnoty, které stojí za to, aby byly cílem životního směřování a usilování, a ukazují cesty, které $\mathrm{k}$ nim vedou. $\mathrm{V}$ plném souladu zde stojí Boží království, kde člověk uzří Boha a bude plně prožívat, že je Jeho

\footnotetext{
${ }^{7}$ Zisk může být i záporný, což znamená ztrátu. Přichází-li v úvahu jedině ztráta, pak maximalizace zisku znamená minimalizaci ztráty.

${ }^{8} \mathrm{~V}$ běžném jazyce je samo slovo blaho někdy chápáno z morálního hlediska mírně negativně. Jeho morálně pozitivní přijímání se promítá do používání odvozeného příslovce "blaze" v Českém ekumenickém překladu Písma sv.

${ }^{9}$ Všeobecně kladné přijímání kapitalismu v postkomunistických státech je způsobeno i silnou negativní zkušeností s tzv. socialismem, a tak se stává, že i křestáané běžně přijímají bez vážnějších námitek systém, který je založen na lži, jíž je idea neomezeného materiálního růstu.
} 
dítětem, s budoucností země (ta patří tichým, pokorným, nenásilným ${ }^{10}$ ), s nasycením (které u Ježiše má jak pozemský, tak i zemské věci přesahující rozměr), s prožíváním milosrdenství. Budoucnost zaměřená k nebi a k zemi splývají.

\subsection{Spasení se týká celého stvoření.}

První kapitola Písma svědčí o tom, že co Bůh stvořil, bylo dobré (srov. čl. 2.1). Harmonie stvoření však byla lidským hříchem narušena (čl.2.2, 2.3). Nicméně Bůh své dílo neopustil. Seslal svého Syna Ježíše Krista, aby vzal lidský hřích i s jeho důsledky na sebe. Dosah Jeho oběti na kř́ži zahrnuje celé stvoření, lidským hříchem zasažené.

Člověk má v biblické zvěsti své zvláštní místo. Jeho stvořením dovršil Bůh tvoření hmotného, smysly vnímatelného světa. (Skutečným vrcholem stvoření je ovšem sabat - den Hospodinova odpočinutí a symbol Jeho slávy.) Lidský hřích se dotýká celého stvořeného světa. Ježíš Kristus trpěl a zemřel proto, aby vzal na sebe lidský hřích se všemi jeho düsledky. Ve svém rozhovoru s Nikodémem shrnuje poselství o Božím vztahu k člověku: „Tak Bůh miloval svět, aby kdo v Něho věří, nezahynul, ale měl věčný život" $(J 3,16)$. Předmětem Boží lásky je celý svět, celý kosmos, všechno stvoření. Kristova obět je skutečně universální. Avšak $v$ moři nekonečné Boží lásky má zvláštní místo ten, kdo věrí. A víra je specificky lidská.

Člověku není dáno, aby mohl během pozemského života obsáhnout Boží lásku v celé její śíríi. Zahrnuje celé stvoření. Jejím vskutku kosmickým dosahem se zabývá apoštol Pavel ve svém listě Římanům (8. kap., zvl. verše 18-27). Kdo tuto lásku proživá, získává k celému stvoření ( $\mathrm{k}$ přírodě, $\mathrm{k}$ životnímu prostředí) vztah jako $\mathrm{k}$ dobrému dílu Božích rukou, které smí užívat (je Božím darem) a o které má odpovědně pečovat (je od Boha svěřeným závazkem). Nelze milovat Boha $z$ celého svého srdce, $z$ celé své duše, $z$ celé své síly a mysli (Mt 22,37, Lk 10,27, Dt 6,5) a necitlivě zacházet s tím, co On stvořil. Nelze milovat svého bližního jako sebe sama (Mt 22,39, Lv 19,18) a přitom s Božími dary nakládat sobecky a bezohledně.

\subsection{Eschatologický výhled}

Ekologickou procházku Písmem jsme zahájili ve 2. kapitole zastavením u biblické zvěsti o stvoření. Nyní stojíme před jejím závěrem, který by měl patřit tomu, co na časové ose stojí kdesi na obzoru před námi. $V$ našem fyzickém světě čas (CHRONOS) znázorňujeme orientovanou př́mkou. Boží čas (KAIROS) má však jistě mnohem komplikovanější strukturu a nejsme oprávněni omezovat jeho dimenzi (přiřazovat mu jednorozměrnost). Některé biblické texty, jako např. janovský prolog $(\mathrm{J} 1,1-5)$, do tajemství Božího času dávají nahlédnout. Svět, kosmos, osvobozený Kristovou obětí, směřuje k Božímu království, které se však dotýká i naší aktuální situace. Věčnost zasahuje do časnosti.

První stránky Písma nejsou prírodovědným pojednáním. Svědčí o smyslu a hodnotě stvoření a o Božím vztahu $k$ světu a k člověku - $k$ jednomu každému z nás. Podobný přístup si zaslouží i eschatologické texty v Písmu, zaměřené na budoucnost z perspektivy Boží lásky $\mathrm{k}$ člověku a $\mathrm{k}$ celému stvoření. Jde jak o svědectví o Kristově vítězství, o vítězství dobra nad zlem (Iz 11,6-9, Zj 21,1-22,5), tak i o líčení apokalyptických hrůz (např. Zj 18,1-19,5, kde

${ }^{10}$ Význam řeckého adjektiva PRAYS je široký a pokrývá významy jemu zhruba odpovídajících adjektiv: pokorný, mírný, tichý, skromný, nenásilný, ... 
poznáváme, jak zavádějící a pomíjivou hodnotou je ekonomická prosperita). Z těchto biblických textů se dovídáme, co před Boží tváří má skutečný smysl, kde jsou skutečné hodnoty, pro něž je dobré a nutné se angažovat (více viz kap. 7).

Bůh, Stvořitel a Pán, stvořil člověka "k obrazu svému" $($ Gn 1,26). Je stále aktivní a na této aktivitě se tedy má člověk podílet $(\mathrm{J} 5,17, \mathrm{~J} 14,12,1$ K 3,9). Tvưrčí úsilí o dobro, směřující k Božímu království, patří k plně prožívanému lidskému životu.

Zde naši „ekologickou procházku Písmem" končíme. Pro aktivní křestáanství důležitější než nauka je životní praxe, a tak se nyní stručně se zamyslíme nad tím, jak se Biblí ovlivněný vztah k životnímu prostředí může promítnout do osobní angažovanosti.

\section{Vzdělání}

Rozum je beze sporu nesmírně vzácným darem, který byl člověku dán. Není však něčím, co by měl člověk plně navíc proti ostatním živým tvorům. $V$ mnoha situacích, kdy jsou jiní živočichové spolehlivě řízeni svými instinkty, je člověk na svůj rozum odkázán. $\checkmark$ určitém smyslu tak lidský rozum nahrazuje vrozené vnitřní programy jiných živočichů. To se týká i vytváření postojů vưči okolí, které tvoří výraznou součást vzdělání.

Není zde naším cílem vzdělání vyčerpávajícím způsobem definovat, ani tento pojem nějak hlouběji analyzovat. Avšak nemůžeme se mu ani zcela vyhnout. Vzdělání budeme chápat jako komplexní formování člověka, zahrnující jak (1) získávání nejdůležitějších poznatků, tak (2) jejich třídění, kritické hodnocení a vytváření souvislostí a (3) odtud vyplývající vytváření postojů a vztahů ke skutečnostem v nejširším smyslu slova (kdy mezi skutečnosti zahrnujeme i myšlenky, hypotézy, teorie atd.).

V čl. 1.5 jsme se zmínili o modelu světa, vytvořeném interdisciplinárně pod vedením manželů Meadowsových. Přes širokou účast nejrůznějších odborníků mu byla vyčítána př́liš technická orientace. Autoři to nepopírali a nepovažovali to za jeho přednost, nýbrž za určité východisko z nouze, způsobené nedostatkem času, omezenými možnostmi tehdejší výpočetní techniky a celkovým stavem poznání. Svět jako takový i ten svět, v němž se člověk se svým rozumem, se svými city i potřebami pohybuje, je nesmírně složitý. Mezi světem př́rodních věd, světem sociálních věd, světem umění a citů existují důležité interakce, které jsme si při našem způsobu zkoumání světa i při našem tradičním způsobu vzdělávání zvykli přehlížet. Avšak chceme-li se na Zemi dívat jako na Boží stvoření, na harmonické dílo „Božích rukou", musíme ji vnímat jako jeden celek. $\mathrm{K}$ tomu ovšem potřebujeme mít co nejvíce informací, potřebujeme co nejvíce znát o zákonitostech, kterými se svět řídí. Sem konec konců mírí i př́kaz k podmanění si země, jak jej čteme v první kapitole Bible - podmaněním je míněno rozumné (a tedy o znalosti opřené) ovlivňování procesů. A často kolem sebe vidíme, že nedostatečné poznání světa je zneužíváno pro různé osobní a skupinové zájmy. Nedostatečné všeobecné vzdělání je živnou půdou pro nejrůznější demagogie, které miŕí proti integritě stvoření.

Velkým nedostatkem našeho poznání je jeho atomizace. Vidíme to např. na tom, jak je obecně přijímán a většinou lidí nekriticky obdivován ekonomický systém, vedoucí, ba často nutící ke zvyšování spotřeby, který je - za předpokladu snahy nezničit život - v rozporu se známými př́rodními zákony. Přirozené etické cítění, znalosti z přírodních věd a ekonomické uvažování tak $v$ mnohých lidech tvoří tři zcela nezávislé, neskloubené složky jejich vztahu ke světu, poznání světa a představ o něm. Tyto složky vytvářejí sporný systém. Široké interdisciplinárně orientované vzdělání vedoucí $k$ vytváření nezávislého kritického myšlení by mělo zabraňovat vytváření takových inkonzistentních názorů a postojů. 
Naše současná vzdělávací soustava se asi v důsledku přežívání starších koncepcí zaměřuje přiliš na předávání poznatků, jejichž objem ve všelidském měřítku roste $v$ takové miře, že vytvoření jakési "mentální encyklopedické databáze" stejně není možné. Přitom postrádá vytváření uceleného, globálního pohledu na svět a život (na jsoucno, na stvoření). Chybí v ní i vytváření vztahů k předmětu poznání.

$\checkmark$ evropské pluralitní společnosti je přirozené, že vzdělávací soustava je nenáboženská. Jako taková sice může redukovat množství předávaných poznatků, vytvářet vazby mezi nimi i určitý osobní vztah odpovídající kulturnímu vývoji, ale od sekulárního (občanského, nenáboženského) školství nelze očekávat ani chtít, aby vedlo k pohledu na svět jako na Boží stvoření, aby učilo príijímat používané věci jako Boží dary. To je úkolem vzdělávání v křest́anském společenství, $v$ církvi.

Dnes bezesporu existuje poměrně široká mezera mezi vědeckým poznáním a encyklopedickým vzděláním na straně jedné a zvěstováním evangelia na straně druhé. Vznikla již v průběhu formování vědy. Evangelium ovšem směřuje $k$ člověku žijícímu v Bohem stvořeném světě a spoustou vazeb provázanému s ostatním stvořením. Bez svého okolí, k jehož poznání věda směřuje, by člověk nebyl člověkem. Bủh nestvořil dva světy, sekulární a náboženský, nýbrž svět jediný. A tak jedním z aktuálních úkolů pro církev je odstranit onu mezeru mezi světem vědy a světem víry. Věda, její poznatky jsou obecné, nenáboženské, avšak její filozofické dotažení a vytváření vztahů na hlubších úrovních již mají náboženský rozměr, souvisejí s vírou. Neexistuje křestáanská přírodověda, avšak existuje křestáanský postoj k předmětu přírodovědy, daný přijímáním stvoření jako dobrého díla Božích rukou.

Evropský dnešek je jistě podstatně jiný, než byla novozákonní Palestina. V životě tamní židovské společnosti hrály významnou úlohu školy - synagogy, poskytující pro tehdejší podmínky komplexní vzdělání. $V$ určitém smyslu byl jejich význam větší než význam chrámu, jehož roli po zkáze Jeruzaléma v rámci daných možností převzaly. A pro formování první církve byla významná kázání v synagogách, at́ již na území Palestiny či v diaspoře. Postupem doby křestanství začalo ztrácet svůj široký "synagogální" záběr a stahovalo se do "chrámového prostoru". Tento proces spolu s vývojem myšlení a poslání vyústil v dnešní odklon od křestáanství, který je ve velké části dřive "křest́anské civilizace" patrný. Návrat $\mathrm{k}$ široké "synagogální" křestáanské zbožnosti je nanejvýš žádoucí. Souvisí to i s angažovaností Ježíšových následovníků v dnešním světě, již je věnována následující kapitola.

\section{Angažovanost má smysl}

Vyslovme nyní dvě teze:

1. Angažovanost pro životní prostředí patří ke křestáanskému životu; pasivita odůvodněná svěřením všech záležitostí do Božích rukou je nepochopením Božího oslovení (srov. Kohák 1997).

2. I to "málo", co pro životní prostředí mohu udělat já, církevní společenství, kam patřím, zájmová organizace, kam patřím, má smysl.

Odůvodnění obou tvrzení podáme současně.

Písmo obsahuje optimistické eschatologické obrazy i líčení apokalyptických hrůz. Někteří křestáané vytvářejí „prognostické" či „futurologické" scénáře, Bible se pro ně stává jakousi alternativou k věštecké křištálové kouli. Písmo však není popisem "systémové trajektorie" světa a lidstva $v$ čase - ani v minulosti, ani v budoucnosti. Je svědectvím o Hospodinu a o Jeho vztahu ke stvoření, zvláště pak člověku. A pro křest́any je Bible především výzvou 
k následování Krista. Neodpovídá na otázku, jak se věci mají, nýbrž na otázku co mám činit, jak $v$ té které situaci mohu a mám následovat Krista? Dává to nejdůležitější pro rozhodování. Avšak zodpovědné rozhodování také vyžaduje o světě hodně vědět. V Písmu můžeme hledat pro konkrétní životní situace odpověd', jak se zachovat. Bohu na člověku, na jeho jednání záleží. Záleží Mu i na tom, jak svým počínáním odpoví na Jeho oslovení.

Člověk byl stvořen k Božímu obrazu (či - podle ekumenického překladu - k Božímu podobenství). Po stvoření následoval hřích, pád. Ježíš Kristus však vzal náš lidský hřích i s jeho důsledky na sebe. Plně lidské je počínat si jako „Boží podobenství". Na našem jednání záleží. Nelze zůstat netečnými vưči Božímu stvořitelskému dílu. Svým jednáním se pro ně musíme angažovat.

Stále však nezodpovězenou zůstává otázka, zda svým jednáním můžeme nějak nevýznamně ovlivnit to, co se na zemi a ve společnosti děje. Osobní angažovanost patří k životní praxí podložené celoživotní modlitbě $(1 \mathrm{Te} 5,17)$. A modlitbě v duchu a pravdě - hluboce prožité a do počínání promítnuté - patři Boží zaslíbení.

Jednotlivci i skupiny mohou svým dobrým zacházením s životním prostředím pro tuto praxi získat další lidi. Větší rozšíření takovéhoto žádoucího napodobení vypadá nepravděpodobně. Avšak Boží zásahy mohou probíhat tak, že dojde $k$ něčemu, co se $z$ hlediska lidského poznání jeví jako sice možné, avšak velmi málo pravděpodobné. Rozsáhlá změna lidského chování může být Boží odpovědí na upřímné modlitby Jeho věrných.

Ke křest́anskému, biblicky motivovanému pohledu na svět patři vděčnost. Hezkou praxí v některých křestáanských rodinách je modlitba před jídlem - avšak důvodem $\mathrm{k}$ vděčnosti jsou i další Boží dary: vzduch s vhodným podílem jednotlivých komponent, energetické zdroje, nerostné suroviny atd. Vděčnost vede k zamyšlení nad osobními nároky a spotřebou.

Lidské rozdělení, neschopnost se domluvit, symbolizovaná věží v Bábel (Gn 11,1-9), má velký podíl na současném stavu životního prostředí. Je třeba spojit síly $\mathrm{k}$ angažovanosti pro Boží stvoření, je třeba usilovat o nápravu $v$ oblasti životního prostředí. $\mathrm{K}$ tomu je nezbytná široká spolupráce všech lidí dobré vůle (Mk 9,38-40). Aktivní osobní i skupinová zaujatost pro životní prostředí může mít i misijní dosah. Krize životního prostředí je, jak zdůrazňoval Josef Vavroušek (1994, 1996; Keller 1995, 1996), krizí hodnotových měřítek. Hodnotám $v$ naší civilizaci běžně príí́maným nemůže patřit budoucnost. Ježíšũv hodnotový systém je k nim nadějnou alternativou.

\section{Závěr}

$Z$ toho, co bylo řečeno, plyne, že angažované křest́anství v sobě zahrnuje i nasazení ve prospěch životního prostředí. Je smutnou pravdou, že $v$ církvích často panuje jakási nedůvěra $k$ ekologům ${ }^{11}$, jimž se - někdy možná i trochu oprávněně - vyčítá, že podporují vznik novodobého pohanství (zbožštování přírody). Na druhé straně se stavějí na odpor proti nejnebezpečnější modle naší civilizace - proti „mamonu" - důrazněji, opravdověji a odpovědněji než mnozí „praktikující” křestané.

\footnotetext{
${ }^{11}$ Ekology zde rozumíme lidi nějakým způsobem se angažující pro životní prostředí, tedy nikoli jen odborníky v prrírodovědné disciplíně - ekologii.
} 
Nový zákon přináší svědectví o tom, že Bůh poslal na svět svého Syna Ježíše Krista, aby na sebe vzal tíhu hříchu i s jeho důsledky. Nedílnou součástí této radostné zprávy evangelia - je zřetelná výzva k pokání, k radikální změně myšlení a jednání, k níž patří i nový přístup ke stvoření. Ježíš přináší člověku svobodu, která tuto změnu umožňuje. Vede k opuštění závislosti na praxi okolí i k opuštění osobního materiálního prospěchu jako rozhodovacího kritéria. Jeho hodnotový systém zdůrazňuje lásku k Bohu i k bližnímu, tichost, pokoru, orientaci za horizont pozemských záležitostí směrem $\mathrm{k}$ nebeskému království. Člověku je dáno vědět, že je předmětem Boží lásky. Starat se o nějaké výsadní postavení před Bohem není na místě. "Stači” vědět, že na Boží lásku projevenou Kristovou obětí Ize spolehnout. Vykoupení člověka z moci hříchu znamená, že se mění i vztahy k celému stvoření. $\mathrm{K}$ odpuštění viny nedílně patří i ono Ježíšovo vysvobozující "nehřeš více" z perikopy o ženě přistižené při cizoložství (J 8,3-11). Evangeliem oslovený člověk je pokorný. Rozhodně se necítí být "korunou stvoření a zároveň ví, že z Boží milosti v něm nemusí ani vystupovat jako „š̌kodná". Opouští násilí jako způsob př́stupu k přírodě. Životní prostředí přijímá jako nedílnou součást Božího díla stvoření, jako Boží dar umožňující život jemu i druhým lidem $\checkmark$ minulosti, $v$ současnosti i v budoucnosti, a nejen lidem, ale obecně, umožňujíć život jako takový. Přijímá je jako dar i jako závazek, patřící k úloze člověka ve velkolepém Božím stvořitelském díle, lidským hříchem narušeném, avšak Kristovou obětí obnoveném $(J 3,16)$.

Kritériem toho, jaký člověk je, je jeho jednání. To, vychází-li z učení Ježíše Krista, je ve vztahu k životnímu prostředí v souladu s orientací ekologů. Přijímání životního prostředí jako Božího stvořitelského díla vede k vědomí hlubokých souvislostí, které v něm jsou. Světu je velmi potřebná angažovanost pro životní prostředí, vyvěrající z opravdové víry, volající k hlubokému pokání a vytvářející nové vztahy člověka ke stvoření, v nichž není místo pro sobecký ani násilnický př́stup.

Současný trend $v$ lidském počínání vưči životnímu prostředí není udržitelný, a to i přes různá dílčí nadějná zlepšení. Změnit jej není jednoduchým úkolem. Proto nelze síly tříštit. Ježíšovým učedníkům kdysi vadilo, že v Jeho jménu konal zázraky někdo, kdo s nimi nechodil. Ježíš jejich postoj odmítl (Mk 9,38-40): „Kdo není proti nám, je pro nás." A tak, přes různá ideová východiska, je žádoucí, abychom - at' už se deklarujeme jako křestáané nebo jako ekologové - spojili své síly a usilovali o zachování celého Stvořitelova velkolepého díla - celé krásné, úžasné, hlubokými vztahy provázané přírody.

\section{Literatura}

- Birch, C., \& Vischer, L. (2007). Život se zviŕaty: Společenství božích tvorů. Praha: Kalich.

- Daly, H. (1973). Toward a Steady-State Economy. San Francisco, Freeman.

- Dubos, R. (1980). The wooing of earth. : London, Athlone Pr.

- Feshbach, M., Friendly, A., (1992). Ecocide in the USSR. New York: Basic Books.

- František (papež), (2015). Laudato si'. Bud' pochválen. Encyklika o péči o společný domov. Z ital. orig. přel. Milan Glaser.. Praha: Paulínky.

- Fromm, E. (1992). Mít nebo být?. Překlad Vlastislava Žihlová. Praha: Naše vojsko.

- Granberg-Michaelson, W. (1988). Ecology and Life. (Issues of Christian Conscience.). : Waco, Word. 
- Heller, J. (2000). Pozdní sklizeň. Praha: Advent Orion.

- Heller, J. (1994). Člověk - pastýř stvoření. Universum, 16, zima 1994/95, 15-67.

- Jančař́ḱková, K. (2015). Ekolístky. II. vydání. Praha: Univerzita Karlova v Praze, Pedagogická fakulta.

- Keller, J. (1995). Přemýšlení s Josefem Vavrouškem. Praha: G plus G.

- Keller, J., Frič, P., \& Gál, F. (1996). Hodnoty pro budoucnost. Praha: G plus G.

- Kohák, E. (1977). Rybáŕi mezi politickými proudy. In: Mezi proudy - sjezd nejen evangelické mládeže. Prostějov.

- Loosli-Amstutz, D. (2014). Příroda je Boží dar: Katechetická příručka. Kokonín: Česká křest́anská environmentální sít.

- Lorenz, K. (1990). 8 smrtelných hříchů. Praha: Panorama.

- Lovelock, J. E. (1993). Gaia. Nový pohled na život na Zemi. Košice: Abies.

- Lovelock, J. E. (2008). Gaia vrací úder: Proč se Země brání a jak ještě můžeme zachránit lidstvo. Praha: Academia.

- Malthus, T. R. (1798). An Essay on the Principle of Population. London: London 1798.

- Meadows, D. L., Meadows, D. H., \& Randers, J. (1972). The Limits to Growth. New York: Universe Books.

- Meadows, D. H., Randers, J., \& Meadows, D. L. (1995). Překročení mezí: Konfrontace globálního kolapsu s představou trvale udržitelné budoucnosti. Praha: Argo.

- Mesarovic, M., \& Pestel, E. (1974). Menschheit am Wendepunkt. Stuttgart: Deutsche Verlag-Anstalt.

- Moltmann, J. (1985). Bůh ve stvoření. Brno: CDK.

- Norberg-Hodge, H. (1996). Dávné budoucnosti. Brno: Hnutí DUHA.

- Nováček, P. (1998). Chválí Tě sestra Země: úvahy o křestanství, životním prostředí a udržitelném rozvoji. Olomouc: Matice cyrilometodějská.

- Česká biskupská konference, (2000). Pokoj a dobro. Praha: ČBK.

- Schumacher, E. F. (1978). Small is Beautiful. London: Sphere Books.

- Světlík, P., Kohoutková, I., \& Soukupová, V. (2003). Zvědy ve vlastní zemi: Křestánské metodické listy, návody pro ekologickou práci s dětmi, př́klady ekologických kázání, liturgie a písní. Česká Skalice: A Rocha - Křestáané v ochraně přírody.

- Stahel, S., \& Drápal, M. (2012). Péče o životní prostředí v církvích: Praktická příručka. Kokonín: Česká křestáanská environmentální sít.

- Szőlős, J. (2001). Krestáanstvo a ekológia. Bratislava: STUŽ/SR. 
- Vavroušek, J. (1995). Hledání možnosti trvale udržitelného rozvoje. Křestáanská revue, 62(2),

- Vavroušek, J. (1994). Hodnoty a trvale udržitelný způsob života. Teologické texty, 5,

- White L., Jr. (1967). The historical roots of our ecologic crisis. Science. 155, 12031207 (1967). DOI: 10.1126/science.155.3767.1203. Online

http://www.cmu.ca/faculty/gmatties/lynnwhiterootsofcrisis.pdf 